\title{
The saga of women's status in ancient Indian civilization
}

\begin{abstract}
Foundation of human civilization and endorsement of its potency are the consequences of prolonged women endeavor, which through its history of superiority and confinement, convey the picturesque of civilization. Since ages, the Indian societal structure has played an active role in stimulating the trends of change in women's status, which with time also proved to be hindrance to the progress of this country. In this context, the study has attempted to emphasize the women's status in ancient Indian civilization based on the ancient scripts and texts. The ancient era has been categorized into four distinct periods viz. the Vedic period, the Epic period the period of Jainism and Buddhism and the age of Dharmaśāstras, Mánusmriti onward. The study has portrayed the relegation of the women's dignified role and position entirely to a subservient one from Vedic period to the period of Dharmaśāstras, Mánusmriti onward.
\end{abstract}

\section{Keywords}

Dharmaśāstras • India • Jainism and Buddhism • Mahābhārata • Rāmāyaṇa $\cdot$ vedic period

(C) University of Warsaw - Faculty of Geography and Regional Studies

\section{Bhaswati Pal}

Department of Geography, University of Kalyani,

Kalyani, Nadia, West Bengal, India

e-mail: bhaswatipal07@rediffmail.com

\section{Introduction}

Women play a key role in strengthening the dynamism of human civilization. According to Altekar (1938, p. 1), "one of the best ways to understand the spirit of a civilization and to appreciate its excellences and realise its limitations is to study the history of the position and status of women in it." Although the ancient Indian texts have focused on women's visibility in this regard, historians, while reconstructing the past, have created certain spaces for women that exist merely within definite parameters (Chakravarti \& Roy 1988). In regard Indian history, women's studies have a tendency to throw light on the broad terminology of women's status, which has, consequentially, focused on a restricted set of queries. These queries, as well as their parameters seek to explore women's roles and positions in different socio-cultural, as well as economic and political spheres of the country (Sharma 2014). Moreover these parameters have tended to create a major lacuna in our perception of the societal structure that had endeavored to shape gender roles and positions in ancient India. The influence of Indian society on gender has varied widely over time and space due to the differences in socio-cultural traditions and practices (Chakravarti \& Roy 1988). Since early times, societal structure has played an active role in stimulating change in women's roles and positions, but with time has also hindered the progress of the country. In this context, this study has made an attempt to assess women's status and to highlight the structural framework of gender relations in ancient Indian civilization.

\section{Materials and Methods}

Based on the ancient Indian manuscripts and texts: the Védas; the Great Epics, the Rámáyana and the Mahābhārata; the
Buddhist texts; the Smritis; the Purānas; and the Dharmaśāstras; this study has made an attempt to assess women's roles and positions in ancient Indian civilization. Following the chronology of the ancient period in Indian history, the study has been confined to four distinct periods: the Early Vedic or Rig Vedic period (1500 BC-1000 BC), the Epic or Later Vedic period (1000 BC-600 BC), the Jainism and Buddhism period (600 BC-200 BC) and the age of Dharmaśāstras, Mánusmriti (200 BC-647 AD).

The Dharmaśāstras are part of Hindu discourse, and the Dharmaśāstras period is considered to be from 600 BC to 200 $A D$. On the other hand Jainism and Buddhism also flourished in ancient India during the same period. Women's status began to decline in 200 BC during the Dharmaśāstras period with Mánu's codification (Mánusmriti) of societal legislation. Therefore, to avoid an overlap of periods and to highlight women's status in ancient Indian civilization irrespective of religious bias, the Jainism and Buddhism period and the period of Dharmaśāstras, Mánusmriti is considered separately as $600 \mathrm{BC}$ to $200 \mathrm{BC}$, and $200 \mathrm{BC}$ to $647 \mathrm{AD}$, respectively.

\section{Discussions}

The Early Vedic or the Rig Vedic Period (1500 BC-1000 BC)

Women were dignified with a respectable status in early Vedic civilization. Dravidian culture "has had a very long history as a referential term for the southern portion of India" (Marr 1975, p. 30), in which women were honored as well as empowered in the affairs of the home and family. They were also honored by their participation in all the socio-cultural activities of early Indian 
civilization. Moreover, "the Aryan culture, based on the Vedic culture, remained the centralizing factor" (Burrow 1975, p. 29) of the early Vedic civilization. Women's freedom to participate in war, gymnastics, archery, horse riding, public activities, education, decision making, and in the selection of male partners has portrayed the nature of women's status in the social canvas of the Rig Vedic period (Altekar 1938). As explained in Devi and Subrahmanyam (2014), the value of women and the respect shown towards them was not only limited to the idea of mistress of the household, rather, women demonstrated huge potential for contributing to human civilization during the Vedic period. The Rg-Vedá-Samihitā text revealed that the "goddess Durgā" (trans. Müller 1869, p. 211); "Aditi, the goddess of freedom" (trans. Müller 1869, p. 243); and Sárasvatī the "best mother, best of rivers, best of goddesses" (trans. Griffith 1896, Hymn XLI) were worshipped with complete dedication. Sculptures representing early Vedic society have also shown that women were placed in a higher status in this society.

Despite the existence of a preference for sons, daughters were always accepted and treated well in early Vedic India, where the "girls' education passes through the stages of Upanayana and Brahmachárya leading to the marital state" (Tharakan \& Tharakan 1975, p. 117). During the Rig Vedic period all genders were offered the privilege of equal educational opportunity to study the Vedāh (Vedic literatures), and the role of women in ancient Indian literature became of great importance. The Rg-Vedá-Samihitā mentioned several women seers and sages, of which Sulabhā Maitreȳ̄, Gārgī Vāchaknavī, Lopāmudra, Ghōṣa, Visvavārā, Vadavā Prāchiteȳ̄, and Sikatā Nivāvarī represented renowned female authors of the Vedic mántras (hymns), as well as being persons of intelligence due to their learning during that era. Early Vedic texts have also revealed two types of women scholars of the period: the Brahmavādínis, women who never married and who studied the Vedāh throughout their lives; and the Sadyodvāhās who studied the Védas until they married. The Vedāhs referred to female teachers as upadhyāyās (unmarried female teachers) or upadhyāyānīs (married female teachers) within Vedic society. The early Vedic period was therefore characterized by women's glorious role in education.

In early Vedic family affairs, women who enjoyed both their autonomy and their role as wives were considered to be ardhangini (better half) and sahadharmini (equal partner). Marriage was never forcibly imposed on women in Rig Vedic society. The Rgg-Vedá-Saṃhitā has often referred to spinsters as "Amajuh, one who grows old in (one's parents') house" (Altekar 1938, p. 38). After puberty and the completion of their education, girls had permission to take up married life by selecting their life partners through swayamvara (choosing a husband). The RgVedá-Saminhitā has disclosed the existence of both polygamy and polyandry during the early Vedic period. In some passages of the Vedāh too, the "wife is mentioned in connection with husbands in plural" (Altekar 1938, p. 132). Remarrying was also socially acceptable for widows; however, divorce was not permitted in Rig Vedic's marriage system. As Bala states (2014, p. 123), "the tradition of child marriage cannot be traced to the Védas." Women were honored as the "very source of Purușārthas, not only Dhárma, Artha and Káma, but even Mokșa" (Nandal \& Rajnish 2014, p. 22) in Rig Vedic India.

Women of the early Vedic period enjoyed absolute economic freedom. They engaged in professions for increasing health and well-being, as well as in teaching professions as achāryās in Rig Vedic society (Altekar 1938). During this period, women also earned money through the spinning and weaving of clothes at home, while also helping their husbands in agricultural activities. However, the Vedāh has emphasized women's greatly restricted right to the inheritance of property, in which married daughters were never allowed to inherit their father's property. However, spinsters had access to patrimony in the form of one-fourth of the share allocated to their brothers.

In addition to this, in early Vedic religious discourses, women had the privilege and full right to regularly participate in ceremonies and rituals. In Rig Vedic society the women would have been honored to carry out sacrifices jointly with their better half. Women also had the liberty to read sacred literature, and also had the right to take part as debaters in public assemblies.

Special attention to the female's priority and satisfaction during sex has been markedly observed in Vātsyāyana's Kāmasūtra, which highlights the Rig Vedic's sexual eroticism and emotional fulfillment in life (trans. Fosse 2012). Moreover, Jayadeva's Ratimañjari (based on the Kāmasūtra) has thrown a light on a profound illustration of káma during the Rig Vedic period (trans. Rossella 2010). As written in the Ratimañjari, other than being described as wives, girlfriends, or prostitutes; women were, significantly, considered to be partners in giving pleasure to men and for being completely satisfied by him at the same time in the area of sex (trans. Rossella 2010). In the Rig Vedic civilization, prostitutes, along with their practices, were never considered to be undignified or shameful, rather female sex workers were depicted as classy women, without societal restrictions (Nandal \& Rajnish 2014). In the Arthaśāstra, while emphasizing the legal position of prostitutes during the Rig Vedic period, Kautilya referred to several special classes of prostitute: Ganiká, Rúpájíva, Vésya, Pratiganiká, Dási, Devadási, and Rúpadási (trans. Shamasastry 1956). Besides, prostitutes were also portrayed as being beautiful, talented, and prosperous within this societal canvas (trans. Shamasastry 1956). Moreover, a broad understanding of sexuality through tantra sex (divine prostitution) has been revealed in early Vedic society. Thus the Rig Vedic civilization endeavored to create a picture of the idyllic conditions of women's sexuality (Chakravarty 1988).

\section{The Epic or Later Vedic Period (1000 BC-600 BC)}

Womanhood was idealized as an honorable position both in and outside the home during the Epic period of Indian civilization. The two great epics of India, the Rāmāyana by Válmíki and the Mahābhārata by Krishna-Dwaipayana Vyasa, depicted women as the root of dharma, pleasure, and prosperity. According to Thakur (2017, p. 382), "the bride is designated as the queen of the house whose position is supreme above all the members of groom's family." The Rāmāyana emphasized the line "tell of Sítá's noble life" (trans. and ed. Griffith 1870-1874, p. 31). Moreover, Sítá, Draupadi, Kaikeyi, Rukmani, Sabitri, and Satyabhama symbolized the great value, strong willpower, and the courageous role and position of women in Epic society.

In the Rāmāyaṇa, ideal womanhood was well illustrated as glorifying the value of pativratya (devotion to one's husband) and has also idealized Sítá as the "best of womankind" (trans. and ed. Griffith 1870-1874, p. 493) and the most esteemed aspect of Indian heritage. Sítá has been symbolized as a devoted wife in the Rāmāyaṇa, representing the ideal character that all women were expected to strive towards (Wadley 1977). However, during the Epic period, "in later Vedic literature it is pointed out in several places how polyandry is not permissible, though polygamy is legal" (Altekar 1938, p. 132). Traditionally, the life and characters of Sāvitrī, Sítá, Anusūyā, Damayanti, and Arundhatī have also been widely celebrated as pativratas in the Rāmāyana and Mahābhārata (Kang 2015).

Women possessed unconditional economic freedom during the Epic civilization period, while the Mahābhärata upheld the religious importance of the mother in the betterment of the family. As Ganguli indicated (1883-1896), the character as well as the contribution of the Mothers, that is, Gañgā, Gāndhārī, Pārvatī, 
Uttarā, and Kuntī, towards their families' benediction was considered worth mentioning in the Mahābhārata.

The prevalence of the devadási practice emerged during the Epic period, in which women were psycho-sexually devoted to the gods. Being recognized as devadásis, these dedicated girls were bound to spend the rest of their lives serving the priests and the pilgrims (Das 2017).

Women were given "sexual liberty" (Ganguli 1883-1896, Section XXX, p. 65), and higher roles and positions in war, during the Epic period of Indian civilization. The Rāmāyana and the Mahābhārata offer a picture of Kșatriya women taking part in wars to defend and protect their culture. On the other hand, the Mahābhārata also disclosed men's dependency on women in the area of sex during the Epic period (Ganguli 1883-1896).

\section{The Jainism and Buddhism Period (600 BC-200 BC)}

The existence of a persistent gender equity was observed during the period of Jainism and Buddhism. In the Tipitaka, the "Vimana Vatthu Pali" (ed. Ko Lay 1990, p. 139) section of the "Khuddaka Nikaya" (ed. Ko Lay 1990, p. 133) chapter portrays women's freedom in education, and religious and cultural activities in society. During this period the various Indian cultures were "united by a common culture, of which the Aryans were the original founders, but to which Dravidians and others also made their contributions" (Burrow 1975, p. 29).

During the period of Jainism and Buddhism, Buddhist philosophy encouraged women to lead a liberal and honorable life. Moreover, the Tipitaka disclosed the "admission of bhikkhunis in order" (ed. Ko Lay 1990, p. 23), and emphasized that the Buddha considered women "capable of attaining Magga and Phala insight" (ed. Ko Lay 1990, p. 23). Women were found not to be just restricted to domestic jobs but also able to pursue educational careers if they desired. Sanghamitra, the daughter of Ashoka, was able to get herself inducted into the preaching of Buddhism. With regards to the Jain texts, Jayanti, the Kaushambi princess remained a spinster in order to study philosophy and religion. Moreover Buddhist nuns were found to have composed hymns, while other women were, significantly, observed to have written Sanskrit plays and verses. They also achieved excellence in painting, music, and other fine arts.

During the period of Jainism and Buddhism, women occupied esteemed positions in religion and were permitted to become Sanyāsinis. In the Tipitaka, women "left the household life like their menfolk" (ed. Ko Lay 1990, p. 23) to lead a Buddhist monastic-life during this period. Women who had superior intellect had enough confidence to run their own sangha (also known as bhikkhunisangha), as directed by a set of legislation, which was not gender-biased. Women were also observed to involve themselves in participation in socio-cultural services and activities, creating abundant prospects for public life.

However, women's economic status deteriorated during the Jainism and Buddhism period, in which they were also prohibited from political participation. The low politico-economic status of nuns compared to that of monks indicated a deterioration in women's roles and positions during the of Jainism and Buddhism period.

\section{The Age of Dharmaśāstras, Mánusmriti (200 BC-647 AD)}

Women's right to education was fully withdrawn with Mánu's codification of the laws governing society. During the age of Dharmaśāstras (the rules of right conduct), Mánusmriti, a number of problems started to creep in with the introduction of various restrictions on women's ability to obtain an education.

Pre-puberty marriage (child marriage) occupied a significant place in societal customs and husbands were given the status of god during the age of Dharmaśāstras, Mánusmriti (Altekar 1938).
In the Arthaśāstra, while explaining "the duty of marriage, the property of a woman, and compensations for remarriage" (trans. Shamasastry 1956, p. 222), Kautilya stated that men, "having given his wives the proportionate compensation and an adequate subsistence (vritti), he may marry any number of women; for women are created for the sake of sons" (trans. Shamasastry 1956, p. 222)

Apart from this, motherhood had been "glorified as compensation for an imposed reality in which women merely gratified society's preference for male progeny" (Bhattacharii 1990, p. WS50). During this age, the contribution of women to society was always outshone by that of the men. Self-sacrifice and the observation of social rituals for the welfare of the male members of their family was considered to be a woman's duty. As in Súdraka's Mṛcchakațikā (500 AD), the custom of avagunthana, also named purdah, began approximately $100 \mathrm{BC}$; it was also practiced by married females while going about in public (trans. Basham \& Sharma 1994). Moreover, the act of widow's remarrying was strictly declared illegitimate, while the prevalence of satī, or sahagamana, increased markedly in society (Altekar 1938).

Mánu's codification of social norms considered women to be impure as well as second class citizens. Following from this, a strict prohibition and oppression of women offering prayers, sacrifices, and undertaking pilgrimages, was declared during the of Dharmaśāstras, Mánusmriti period. In addition, they were strictly prohibited from practicing penance.

Women were completely deprived of inheriting any share of their husband's property under the-then Indian socio-economy. The Arthaśāstra disclosed that "no woman shall succeed in her attempt to establish her title to the property of her husband" (trans. Shamasastry 1956, p. 220). Furthermore, Mánu's codification declared that women would be dispossessed of any sort of property inheritance and thus snatching away women's independence. In the Mánusmriti, while codifying "the duties of women" (trans. Buhler 1964, p. 33) Mánu stated that "by a girl, by a young woman or even by an aged one, nothing must be done independently, even in her own house" (trans. Buhler 1964, p. 33). These laws also stated that "in childhood a female must be subject to her father, in youth to her husband, when her lord is dead to her sons; an women must never be independent" (trans. Buhler 1964, p. 33).

During this period "the growth of monogamous families with insistence on female chastity indicated the direct influence of economic developments in favour of male domination" (Tharakan \& Tharakan 1975, p. 119). According to Wadley (1977, p. 119) "the basic rules for women's behavior, as expressed in the Laws Mánu, ca. A.D. 200, stress the need to control women because of their evil character." Mánu's codification also asserted that females were not at all independent, either in childhood or adulthood, nor when she is aged (Wadley 1977). Moreover, women's character was depicted as being fully malevolent in which they became possessed and acted like slaves in order to satisfy the uncontrollable vice of masculine demand and sexuality. Therefore, the age of Dharmaśāstras, Mánusmriti, was characterized by the subordination of women's status.

The Relegation of Women's Status from the Vedic period to the Period of Dharmaśāstras

In the subsequent period to the Dharmaśāstras, Mánusmriti with the introduction of Brahmanism, the dignity and fame of women's status was entirely reduced to one of virtual subservience. The conflicting social and religious thoughts converted the position of women in to a subordinate and unsatisfactory one (Halli \& Mullal 2016). During the age of the Smritis (Holy Scriptures of Hindu) women had the right to attain 
an education related only to household purposes. Moreover, as written in the Arthaśāstra (350 BC-275 BC), being deprived of formal education, girls were considered to be an inconsequential section within a patriarchal society (Jaiswal 2001). Women were not only deprived of learning the Védas but also had a strict prohibition on becoming Brahmacharinis. Gender inequity had started to creep into society during the Dharmaśāstras, Mánusmriti period, and gradually women's positions were degraded to such an extent that they were deprived of all sorts of freedoms. Women were restricted in exercising their human rights as well as being barred from enjoying fundamental freedoms. A preference for sons was at its apex during this period, which, too, curtailed the freedom of women and girls (trans. Shamasastry 1956, p. 222). Hence the roles and position of women was gradually turned around through the major changes that occurred during the period of Dharmaśāstras, Mánusmriti. During this period the "caste hierarchy and gender hierarchy are the organising principles of the brahmanical social order and closely interconnected" (Chakravarti 1993, p. 579). Women were also barred from practicing religious activities, although women who devoted themselves to being sati by burning themselves on their husbands funeral pyre were honored as well as proclaimed goddesses by the patriarchal society (Wadley 1977). Moreover, being gender prejudiced, the-then Brahmanical society stressed its power over women's sexuality. The Mánusmriti (200 BC-200 AD) stated that a woman's submission to male control in any sexual relationship was the principal duty of her life (Wadley 1977). In the prologue to Mánu's codification of societal rules "the concept of women as chattel or a commodity for a man's enjoyment is borne out" (Saxena 2006 , p. 5). Thus, women's unsatisfactorily subordinate position in the Dharmaśāstras period jeopardized not only women's status and security, but also the socio-cultural as well as the politicoeconomic stability and well-being of Indian civilization.

\section{Conclusion}

The dignified role and position of women in the early Vedic period, the Epic period, and the Jainism and Buddhism period was completely reduced to one of virtual subservience during the age of Dharmaśāstras, Mánusmriti. Although the Mánusmriti considered women's subordination to be a common phenomenon, the socio-cultural set-up further hardened the form and extent of women's confinement during the age of Dharmaśāstras, Mánusmriti. During the period 1500 BC to 647 $A D$, the deterioration in women's roles and position can be attributed to the imposition of Mánu's codification of social rules, gender based discrimination, Brahmanical austerity applied to the entire Indian society, the crudest materialization of women, the implementation of rigid restrictions induced by the societal caste system and the system of joint families, women's exclusion from educational facilities, foreign invasions, as well as the introduction of non-Aryan females as wives in Aryan families. Historical studies and women's contemporary status have disclosed that although Indian society has never accepted womanhood as being equal since the age of Dharmaśāstras, Mánusmriti, even today women's stories are reflected repeatedly as interesting episodes from the ancient period of Indian civilization.

\section{Acknowledgement}

The author would like to acknowledge the University of Kalyani, West Bengal, India for providing financial assistance in the form of a fellowship under the scheme of University Research Scholar (URS) in carrying out this research.

The author would also like to extend sincere gratitude to Dr. Tarun Kumar Mondal, Ph.D. Supervisor and Assistant Professor, Department of Geography, University of Kalyani, West Bengal, India for his guidance in this research.

\section{References}

Altekar, AS 1938, The position of women in Hindu civilization: From prehistoric times to the present day, Benares Hindu University Press, India.

Bala, I 2014, 'Status of women in Vedic literature', The International Journal of Humanities \& Social Studies, vol. 2, no. 6 , pp. $123-127$.

Bhattacharji, S 1990, 'Motherhood in ancient India', Economic \& Political Weekly, vol. 25, no. 42/43, pp. WS50-WS57.

Buddhist Sangha 100 BCE, The Tipitaka, ed. U Ko Lay 1990, Guide to Tipitaka, Burma Pitaka Association Editorial Committee, Buddha Dharma Education Association Inc., Myanmar.

Burrow, T 1975, 'The early Aryans' in A Cultural History of India, ed. AL Basham, Oxford University Press, London, pp. 20-29.

Chakravarti, U \& Roy, K 1988, 'In search of our past: A review of the limitations and possibilities of the historiography of women in early India', Economic \& Political Weekly, vol. 23, no. 18, pp. WS2-WS10.

Chakravarti, U 1988, 'Beyond the Altekarian Paradigm: Towards a new understanding of gender relations in early Indian history', Social Scientist, vol. 16, no. 8, pp. 44-52.

Chakravarti, U 1993, 'Conceptualising Brahmanical patriarchy in early India: Gender, caste, class and state', Economic \& Political Weekly, vol. 28, no. 14, pp. 579-585.

Das, S 2017, 'Esteem of women in Vedic India', Religious and Spirituality. Available from: <https://www.thoughtco.com/ esteem-of-women-in-vedic-india-1770409>. [29 April, 2018].

Devi, NJ \& Subrahmanyam, K 2014, 'Women in the Rig Vedic Age', International Journal of Yoga-Philosophy, Psychology and Parapsychology, vol. 2, no.1, pp.1-3.
Halli, CS \& Mullal, SM 2016, 'Status of women in India' - Status of ancient, medieval and modern', Imperial Journal of Interdisciplinary Research, vol. 2, no. 2, pp. 297-300.

Jaiswal, S 2001, 'Female images in the Arthaśāstra of Kautilya', Social Scientist, vol. 29, no. 3/4, pp. 51-59.

Jayadeva (1170-1245), Ratimañjari, trans. D Rossella 2010, The Ratimañjari by Jayadeva in Nature in Literature, Art, Myth and Ritual, vol. 4, no. 1, Publication of Charles University, Prague, pp. 139-178.

Kang, M 2015, 'The making of womanhood in early India: Pativrata in the Mahabharata and Ramayana', Journal of Social Sciences - Sri Lanka, pp. 206-212.

Kautilya 350 BC-275 BC, Arthaśāstra, trans. R Shamasastry 1956, Kautilya's Arthaśāstra (Translated in English), Sri Raghuvir Printing Press, Mysore.

Krishna- Dwaipayan Vyasa 400 BCE, The Mahābhārata, trans. KM Ganguli 1883-1896, The Mahābhārata of KrishnaDwaipayana Vyasa: Translated into English Prose from the Original Sanskrit Text, vol. 12, Bhārata Press, India.

Mánu 200 AD, Mánusmriti: The Laws of Mánu, trans. G Buhler 1964, Mánusmriti: The Laws of Manu, Translated in 1886, Motilal Banarsidas, Delhi.

Marr, JR 1975, 'The early Dravidians' in A Cultural History of India, ed. AL Basham, Oxford University Press, London, pp. 30-37.

Nandal, V \& Rajnish, M 2014, 'Status of women through ages in India', International Research Journal of Social Sciences, vol. 3, no. 1, pp. 21-26.

Saxena, M 2006, 'Ganikas in early India: Its genesis and dimensions', Social Scientist, vol. 34, no. 11/12, pp. 2-17. 
Sharma, A 2014, 'Status of women: A socio-historical analysis in different ages of Indian society', Research Journal of Language, Literature and Humanities, vol. 1, pp. 10-14.

Sūdraka (500 AD), Mrcchakațikā, trans. AL Basham \& A Sharma 1994, The little clay cart: An English translation of the Mrcchakațikā of Śūdraka as adapted for the stage by AL Basham, State University of New York Press.

Thakur, P 2017, 'A journey of Hindu women from Shakti to Sati in ancient India', International Journal of Engineering, Technology, Science and Research, vol. 4, no. 6, pp. 383-385.

Tharakan, SM \& Tharakan, M 1975, 'Status of women in India: A historical perspective', Social Scientist, vol. 4, no. 4/5, pp. 115-123.

Válmíki 500 BCE, The Rámáyana, trans. and ed. RTH Griffith 1870-1874, The Rámáyana of Válmíki: Translated into English verse, vol. 1, Trübner and Company, London.

Vātsyāyana (400 BC-200 AD), The Kāmasūtra, trans. LM Fosse 2012, The Kamasutra: The original sanskrit / Vatsyayana ; An English translation, United States of America.

Vedavyasa 1500 BCE-1000 BCE, Rg-Vedá-Saṃhitā, The Sacred Hymns of the Brāhmanas, vol. 1, trans. FM Müller 1869, Trübner and Company, London.

Vedavyasa 1500 BCE-1000 BCE, Rg-Vedá-Saṃhitā, trans. RTH Griffith 1896, The Rig Veda English translation. Available from: <http://www. sacredtexts. com/hin/rigveda>. [16 January 2019].

Wadley, SS 1977, 'Women and the Hindu tradition', Signs: Journal of Women in Culture and Society, vol. 3, no. 1, pp. 113-125. 